\title{
Erratum to: Cod Heads, Stockfish, and Dried Spurdog: Unexpected Commodities in Nya Lödöse (1473-1624), Sweden
}

\author{
Emma Maltin $^{1} \cdot$ Leif Jonsson ${ }^{2}$
}

Published online: 20 April 2017

(C) Springer Science+Business Media New York 2017

\section{Erratum to: Int J Histor Archaeol DOI 10.1007/s10761-017-0405-6}

In the above-mentioned article, the author names Emma Maltin and Leif Jonsson were written incorrectly; the given name and family name were interchanged. The original article has been corrected. 